Article

\title{
Comparison of some serum biochemical parameters between lactating and non- lactating dairy cows in selected dairy farms of Chittagong district of Bangladesh
}

\author{
Md. Samun Sarker ${ }^{1 *}$, Md. Ahaduzzaman ${ }^{2}$, Md. Abu Sayeed ${ }^{2}$, Rajib Sarker ${ }^{3}$, Minhazul Abedin Nanno ${ }^{4}$, Abdul \\ Mannan $^{5}$ and Mohammad Belayet Hossain ${ }^{6}$ \\ ${ }^{1}$ Department of Microbiology and Veterinary Public Health, Chittagong Veterinary \& Animal Sciences University, \\ Bangladesh \\ ${ }^{2}$ Department of Medicine and Surgery, Chittagong Veterinary \& Animal Sciences University, Bangladesh \\ ${ }^{3}$ Executive-Technical services at AMAN Group LTD, Bangladesh \\ ${ }^{4}$ Department of Animal Science and Nutrition, Chittagong Veterinary \& Animal Sciences University, Bangladesh \\ ${ }^{5}$ Veterinary Surgeon, S.A.QuaderiTeachingVeterinaryHospital, Chittagong Veterinary \& Animal Sciences \\ University, Bangladesh \\ ${ }^{6}$ Department of Physiology, Biochemistry and Pharmacology, Chittagong Veterinary \& Animal Sciences \\ University, Bangladesh
}

*Corresponding author: Md.SamunSarker, Department of Microbiology and Veterinary Public Health, Chittagong Veterinary \& Animal Sciences University, Bangladesh. Mobile: +8801723375703; E-mail: samun_cvasu@yahoo.com

Received: 23 July 2015/Accepted: 30 August 2015/Published: 30 September 2015

\begin{abstract}
Physiological status-related changes in serum biochemical values are known to occur in many species. The aim of the current study was to evaluate total serum protein, albumin, glucose, calcium and phosphorus concentration and these parameters were measured by the serum analyzer for lactating $(n=50)$ and non-lactating $(\mathrm{n}=50)$ dairy cattle in selected dairy farms of Chittagong district. The results (mean \pm standard deviation) of the study showed that among serum biochemical parameters total protein $(82.3 \pm 2.15 \mathrm{gm} / \mathrm{l})$, albumin $(27.45 \pm 5.06$ $\mathrm{gm} / \mathrm{l})$, calcium $(12.97 \pm 6.67 \mathrm{mg} / \mathrm{dl})$ and phosphorus $(7.26 \pm 0.41 \mathrm{mg} / \mathrm{dl})$ level in non-lactating cows were higher than the value of lactating cows as $(81.28 \pm 2.41 \mathrm{gm} / \mathrm{l}),(14.09 \pm 2.05 \mathrm{gm} / \mathrm{l}),(10.05 \pm 2.51 \mathrm{mg} / \mathrm{dl})$ and $(6.52 \pm 0.30$ $\mathrm{mg} / \mathrm{dl})$ respectively. Only glucose level in lactating cows $(63.01 \pm 6.67 \mathrm{mg} / \mathrm{dl})$ was found higher than the non lactating cows $(58.47 \pm 3.84 \mathrm{mg} / \mathrm{dl})$. In case of parity-wise parameters insignificant variation was noticed. It may be concluded that biochemical variation present between lactating cow and non lactating cow is important for interpretation of laboratory data and also for physiological diagnosis.
\end{abstract}

Keywords: dairy cow; lactating cow; non lactating cow; serum biochemistry; parity

\section{Introduction}

Blood is the fluid connective tissue peruses an immediate indication of an animal's nutritional status at that point in time. Nutritional concentrations in blood represent an integrated index of the adequate supply of nutrient in relation to nutrient utilization of dairy cows. Metabolite levels in blood serum also indicate the extent of body metabolism, such as energy, proteins and minerals (Ndlovuet al., 2007). In like manner these parameters are influenced by both intrinsic and extrinsic factors like breed, age, sex, lactation, pregnancy, health and nutrition status of the cows (Aengwanich, 2002; Al-Shami, 2007; Mohammed et al., 2007). Henceforth the changes in biochemical and hematological constituents are important prerequisites to assess the physiological or pathological state of the animal (Ahmed et al., 2009; Hassan et al., 2012). Blood tests from farm animals are routinely used to extract pertinent information relative to herd nutrition and help to diagnose metabolic disease problems in dairy cows (Van Saun and Wustenberg, 1997). On the other hand, in advanced animal husbandry practice the importance of 
hematoma-biochemical parameter indices are well documented, acknowledged and improving day by day (Opara et al., 2006). In dairy herd, it is important to realize that lactation and the dry period are two important physiological statuses considered to modify the hematoma-biochemical variables in cows because of pattern of demand and supply of nutritional plan (Iriadam, 2007; Tanritanir et al., 2009). Indeed, animals require minerals such as calcium $(\mathrm{Ca})$, magnesium $(\mathrm{Mg})$, and phosphorus $(\mathrm{P})$ for contemporary maintenance or further growth, reproduction and lactation (Tanritanir et al., 2009; Samardzija et al., 2011). Feeding of non-lactating or milking cow low in essential energy and minerals leads to clogging down the homeostatic mechanisms, rendering the cow ready for the massive draw on further production. This is relevant since blood constituent's has been changed in relation to the physiological conditions of animals (Etim et al., 2014). According to Daramola et al., (2005), hematological values could serve as baseline information for comparisons of nutrient trends in different lactation and parity. Although some variation has also been observed in the hematological parameters between breeds of farm animals (Tambuwal et al., 2002), in this regard, it may be difficult to formulate a universal blood metabolic profile test for animals. These differences have underlined the need to establish appropriate physiological baseline values for various breeds, farming and environmental condition of livestock. Therefore, the present study was undertaken to estimate the selected hematological nutritional status of crossbred dairy cows in Bangladesh in relation to age, parity and lactation.

\section{Materials and Methods}

\subsection{Study area and duration}

This study was conducted for a period of 4 months $\left(10^{\text {th }}\right.$ January to $10^{\text {th }}$ April, 2014) in three selected dairy farms in Chittagong city. The farms were selected based on population size greater than 50 crossbred (Holstein Friesian $\times$ Local) cows, house in tie-stall barn, standard ration feeding based on productive performance, milk yield more than or equal to ten litres per day, record keeping history, immunization against infectious disease and acceptance of farm to contribute in research work.

\subsection{Study population}

The study population was 100 cross bred (HF $\times$ Local) healthy cows. In the farms, cows were in different age and production status, from which 50 lactating and 50 non lactating (dry) cows were selected based on parturition record for the first time, but not exceed for more than three times. Cows were further grouped into three categories on the basis of calving history (parity) of which parity $1(n=29)$, parity $2(n=52)$ and parity $3(n=19)$. Some of the dry cows were pregnant, but they were not grouped further. All animals were fed both roughage and concentrates. Normal feeding habits of animals were observed during the research activities. All animals involved in this study were clinically healthy and to ensure this clinical history was reviewed with the farm manager through the examination of physical condition.

\subsection{Sample collection and processing}

All blood samples were collected between 10 am to $12 \mathrm{pm}$ in order to standardize time. Blood samples were taken from jugular vein puncture with proper aseptic measures. About $5 \mathrm{ml}$ of blood was collected and kept in the vacationer tube (without anticoagulant). The samples were transported to the Department of Physiology, Biochemistry and Pharmacology at Chittagong Veterinary and Animal Sciences University (CVASU), Bangladesh for analysis. After coagulation, coagulated blood was centrifuged in 3000rpm for 15 minutes. Serum was transferred to the Eppendorf tube by using micropipette. The obtained serum samples were stored in $-20^{\circ} \mathrm{C}$ for biochemical test and total protein, albumin, glucose, calcium and phosphorus of blood serum were determined according to the biochemical analyzer manual (Humalyzer 3000, Germany ${ }^{\mathrm{R}}$ ).

\subsection{Statistical analysis}

Obtained laboratory data was stored in Microsoft Excell-2007 and imported to the software STAT/IC-13.0 for analysis. Descriptive statistical analysis was done to measure the mean, SEM, 95\% confidence interval (CI) and pvalue of different parameters. The arithmetic means $( \pm \mathrm{SE})$ serum biochemical parameters in different groups were calculated. PAIRED T-TEST was done to assess the biochemical parameters in crossbred lactating and non lactating cows. Further Kruskal-Wallis has been done for unequal variance analysis, among the different parity. In all cases the level of significance was determined at $\mathrm{p}<0.05$.

\section{Results and Discussion}

Total protein levels in both lactating and dry cow were higher than the reference value, but the variation was insignificant between the lactating and dry group of cows. Serum albumin level was found lower in both groups 
than the standard value and variation between the groups was highly significant. Findings for serum glucose, calcium and phosphorus level were within the reference range and their variations were insignificant (Table 1). According to parity, total protein level were found elevated than the reference value and the insignificant variation were shown among the different parity where lowest value was found in the third parity followed by first and second parity. On the other hand alike serum protein the serum albumin level was found lower in all three parities in which lowest value was found in parity two followed by parity three and parity one even though there variations were insignificant. However the serum glucose level was found in decreasing trend with insignificant variation in relation to parity proceed. Serum calcium and phosphorus level were followed almost similar trends and found higher at second parity (Table 2). Within parity 1 serum total protein, albumin and phosphorus level were higher in the non lactating cows than the lactating whereas in parity 2 albumin and glucose level was higher in non lactating cows. Conversely, in the case of third parity total protein, glucose, calcium and phosphorus level were found higher in lactating cows in comparison to the non lactating cows. Overall variation within the parity were insignificant $(\mathrm{p}>0.05)$ (Table 3).

Total protein in serum in lactating and non lactating cows were $81.28 \pm 2.41(\mathrm{gm} / \mathrm{l})$ and $82.32 \pm 2.15(\mathrm{gm} / \mathrm{l})$ respectively. The results of the current study were similar with Peterson et al., (1981) where total protein levels were reported to be higher in non lactating cows $(90.23 \pm 0.23 \mathrm{gm} / \mathrm{l})$ than lactating cows $(70.73 \pm 0.09 \mathrm{gm} / \mathrm{l})$. Conversely, the total serum protein in lactation period $(60.32 \pm 0.60 \mathrm{gm} / \mathrm{l})$ was slightly higher than the dry period $(60.17 \pm 0.89 \mathrm{gm} / \mathrm{l})$ reported by Giuseppe et al., (2012). Serum total protein value in mixed race of Austrian Bălţat

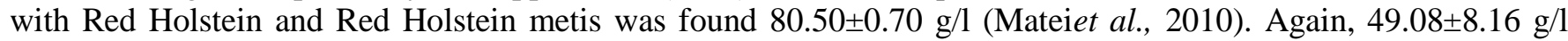
value was found from twenty pregnant Freizian cows in Saudi Arabia (Al-Mujalli, 2008). In another study, the value of total protein in Holstein dairy cows was mentioned $82 \pm 6.10 \mathrm{~g} / \mathrm{l}$ by Cozziet al., (2011). Manzooret al., (2008) stated that, biochemical parameter of blood serum was higher in non lactating cow than in lactating cows. There is a general modification in animals in serum proteins with advancing age and in the very old cows (Kaneko et al., 1997).

Albumin in non lactating cows $(27.45 \pm 5.06 \mathrm{gm} / \mathrm{l})$ was higher than the lactating cows $(14.09 \pm 2.05 \mathrm{gm} / \mathrm{l})$ with significant variation. Similarly Peterson et al., (1981) reported that, albumin was higher in dry cows $(30.97 \pm 0.14$ $\mathrm{gm} / \mathrm{l})$ than lactating $(30.87 \pm 0.06 \mathrm{gm} / \mathrm{l})$. In contrast albumin value was found higher in lactating than non lactating cows (Giuseppe et al., 2012). Serum albumin parameter in mixed race with Austrian Bălţat with Red Holstein and Red Holstein metis was found 30.50 $\pm 0.20 \mathrm{~g} / \mathrm{l}$ (Mateiet al., 2010). In another study the overall mean value of albumin was found $15.13 \pm 6.33 \mathrm{gm} / \mathrm{l}$ from twenty pregnant Friesian cows in Saudi Arabia (Al-Mujalli, 2008). In addition albumin reference value $37 \pm 2.50 \mathrm{gm} / \mathrm{l}$ was reported by Cozziet al., (2011) in the Holstein dairy cows. Higher protein rich feed intake is responsible for higher albumin concentration in blood serum. Lower serum albumin level in lactating cow is related to higher milk production of animal and depletion of albumin for maintaining milk production. The concentration of albumin was influenced not only by the physiological condition of the animal, but also by nutrition (Kaneko et al., 1997).

The glucose level in lactating cows $(63.02 \pm 6.67 \mathrm{mg} / \mathrm{dl})$ was higher than the non lactating cows $(58.47 \pm 3.84$ $\mathrm{mg} / \mathrm{dl})$ that differ insignificantly. Peterson et al., (1981) reported that glucose was higher in dry cows $(69.8 \pm 3.7$ $\mathrm{mg} / \mathrm{l})$ than lactating cows $(65.2 \pm 1.7 \mathrm{mg} / \mathrm{l})$. The blood glucose level is regarded as one of the indicators of energy status in the cow. The blood glucose level was higher in lactating cows this may be due to high energy diet feeding during lactation period and also for taking the extra amount of feed than the requirement of animal for milk production and maintenances. Other research by Cozziet al., (2011) in Holstein dairy cows reviled $58 \pm 0.40 \mathrm{mg} / \mathrm{l}$. In a yearlong study of five upazila namely KhagrachariSadar, Laxmichari, Matiranga, Mahalchari and Dighinala in Khagrachari Hill District of Bangladesh serum glucose level was found $69.21 \pm 2.31 \mathrm{mg} / \mathrm{l}$ in indigenous cattle (Mamun et al., 2013).

Calcium level was found slight lower $(10.05 \pm 2.51 \mathrm{mg} / \mathrm{dl})$ in lactating cows than the non lactating $(12.97 \pm 6.67$ $\mathrm{mg} / \mathrm{dl})$. This result was supported by Peterson et al., (1981) where serum calcium in dry cows $(10.83 \pm 0.35 \mathrm{mg} / \mathrm{dl})$ was significantly higher than lactating cows $(9.02 \pm 0.14 \mathrm{mg} / \mathrm{dl})$. But this result was not in line with Giuseppe et al., (2012), where a level was found higher in lactation period $(8.03 \pm 0.80 \mathrm{mg} / \mathrm{dl})$ from the dry period $(7.83 \pm 0.76$ $\mathrm{mg} / \mathrm{dl})$. In a previous report serum calcium level was reported as $8.01 \pm 0.32 \mathrm{mg} / \mathrm{dl}$ in indigenous cow of Bangladesh (Mamun et al., 2013). Serum Ca decline at or soon after parturition might be an unavoidable mechanism in dairy cows, especially in aged cows (Horst et al., 1990; Goff et al., 1991) due to the expeditious loss of a by milk synthesis, and less efficiency of Ca absorption by the intestinal transcellular pathway (Horst et al., 1990) and inactivation of the bone Caresorption pathway (Ramberg et al., 1970; Kamiya et al., 2005). 
Table 1.Biochemical parameters in crossbred lactating cows and non lactating cows.

\begin{tabular}{|c|c|c|c|c|c|c|c|c|c|c|}
\hline Parameters & \multicolumn{2}{|c|}{ Total protein $(\mathrm{gm} / \mathrm{l})$} & \multicolumn{2}{|c|}{ Albumin (gm/l) } & \multicolumn{2}{|c|}{ Glucose (mg/dl) } & \multicolumn{2}{|c|}{ Calcium (mg/dl) } & \multicolumn{2}{|c|}{ Phosphorus (mg/dl) } \\
\hline Reference value & $67.4-74.6$ & & $30.03-30.55$ & & $45-75$ & & $9.7-12.4$ & & $5.1-9.3$ & \\
\hline Tested value & Mean \pm SEM & $95 \% \mathrm{CI}$ & Mean \pm SEM & $95 \% \mathrm{CI}$ & Mean \pm SEM & $95 \% \mathrm{CI}$ & Mean \pm SEM & $95 \% \mathrm{CI}$ & Mean \pm SEM & $95 \% \mathrm{CI}$ \\
\hline Lactating cow & $81.28 \pm 2.41$ & $76.43-86.13$ & $14.09 \pm 2.05$ & $9.96-18.21$ & $63.02 \pm 6.67$ & $49.6-76.42$ & $10.05 \pm 2.51$ & $5-15.12$ & $6.52 \pm 0.30$ & $5.89-7.14$ \\
\hline $\begin{array}{l}\text { Non- Lactating } \\
\text { cow }\end{array}$ & $82.3 \pm 2.15$ & $78-86.63$ & $27.45 \pm 5.06$ & $17.28-37.61$ & $58.47 \pm 3.84$ & $\begin{array}{l}50.76- \\
66.18 \\
\end{array}$ & $12.97 \pm 6.67$ & $9.51-16.43$ & $7.26 \pm 0.41$ & 6.43-8.09 \\
\hline $\mathrm{P}$ value & 0.77 & & $0.00 * *$ & & 0.53 & & 0.27 & & 0.07 & \\
\hline
\end{tabular}

$* *=\mathrm{P}<.05$ (significant in 95\% confidence interval). (PAIRED T- TEST)

Table 2.Parity-wise changes of serum biochemical parameters in selected cows.

\begin{tabular}{|c|c|c|c|c|c|c|c|c|c|c|}
\hline Parameters & \multicolumn{2}{|c|}{ Total protein $(\mathrm{gm} / \mathrm{l})$} & \multicolumn{2}{|c|}{ Albumin (gm/l) } & \multicolumn{2}{|c|}{ Glucose (mg/dl) } & \multicolumn{2}{|c|}{ Calcium (mg/dl) } & \multicolumn{2}{|c|}{ Phosphorus (mg/dl) } \\
\hline Reference value & $67.4-74.6$ & & $30.03-30.55$ & & $45-75$ & & $9.7-12.4$ & & $5.1-9.3$ & \\
\hline Tested value & Mean \pm SEM & $95 \% \mathrm{CI}$ & Mean \pm SEM & $95 \% \mathrm{CI}$ & Mean \pm SEM & $95 \% \mathrm{CI}$ & Mean \pm SEM & $95 \% \mathrm{CI}$ & Mean \pm SEM & $95 \% \mathrm{CI}$ \\
\hline Parity 1 & $84.62 \pm 2.47$ & $79.55-89.69$ & $28.53 \pm 7.83$ & $12.49-44.56$ & $67.92 \pm 10.76$ & $45.88-89.96$ & $10.23 \pm 0.63$ & $8.94-11.52$ & $6.62 \pm 0.45$ & $5.70-7.55$ \\
\hline Parity 2 & $80.74 \pm 1.98$ & $76.76-84.72$ & $16.1 \pm 2.25$ & $11.59-20.61$ & $60.46 \pm 3.62$ & $53.20-67.73$ & $10.58 \pm 0.43$ & $9.73-11.44$ & $7.13 \pm 0.39$ & $6.34-7.91$ \\
\hline Parity 3 & $82.12 \pm 3.73$ & $74.27-89.96$ & $18.63 \pm 5.76$ & $6.53-30.72$ & $53.61 \pm 6.50$ & $39.96-67.25$ & $10.76 \pm 0.81$ & $9.07-12.46$ & $6.11 \pm 0.38$ & $5.30-6.91$ \\
\hline $\mathrm{P}$ value (Kruskal Wallis) & 0.5303 & & 0.1588 & & 0.5614 & & 0.4493 & & 0.4303 & \\
\hline
\end{tabular}

Table 3. Comparison of the serum biochemical parameters between lactating ( $\mathrm{L}$ ) and non lactating (NL) crossbred dairy cows according to parity.

\begin{tabular}{|c|c|c|c|c|c|c|c|c|c|c|}
\hline Parameters & \multicolumn{2}{|c|}{ Total protein $(\mathrm{gm} / \mathrm{l})$} & \multicolumn{2}{|c|}{ Albumin $(\mathrm{gm} / \mathrm{l})$} & \multicolumn{2}{|c|}{ Glucose (mg/dl) } & \multicolumn{2}{|c|}{ Calcium (mg/dl) } & \multicolumn{2}{|c|}{ Phosphorus (mg/dl) } \\
\hline Reference value & \multicolumn{2}{|c|}{$67.4-74.6$} & \multicolumn{2}{|c|}{$30.03-30.55$} & \multicolumn{2}{|c|}{$45-75$} & \multicolumn{2}{|c|}{$9.7-12.4$} & \multicolumn{2}{|l|}{$5.1-9.3$} \\
\hline Tested value & Mean \pm SEM & $95 \% \mathrm{CI}$ & Mean \pm SEM & $95 \% \mathrm{CI}$ & Mean \pm SEM & $95 \% \mathrm{CI}$ & Mean \pm SEM & $95 \% \mathrm{CI}$ & $\begin{array}{l}\text { Mean } \pm \\
\text { SEM }\end{array}$ & $95 \% \mathrm{CI}$ \\
\hline Parity $1(\mathrm{~L})$ & $81.11 \pm 3.32$ & $73.99-88.24$ & $18.35 \pm 4.01$ & $9.75-26.96$ & $68.05 \pm 19.90$ & $25.37-110.72$ & $10.75 \pm 0.97$ & $8.66-12.84$ & $6.07 \pm 0.69$ & $4.59-7.54$ \\
\hline (NL) & $88.38 \pm 3.53$ & $80.75-96.01$ & $39.43 \pm 15.40$ & $6.16-72.70$ & $67.79 \pm 7.72$ & $51.11-84.48$ & $9.67 \pm 0.78$ & $7.98-11.37$ & $7.22 \pm 0.56$ & $6.02-8.43$ \\
\hline$P$ value (ttest) & \multicolumn{2}{|l|}{0.1453} & \multicolumn{2}{|l|}{0.1832} & \multicolumn{2}{|l|}{0.9908} & \multicolumn{2}{|l|}{0.3985} & \multicolumn{2}{|l|}{0.2065} \\
\hline Parity $2(\mathrm{~L})$ & $81.8 \pm 2.81$ & $76.03-87.57$ & $14.84 \pm 2.91$ & $8.87-20.82$ & $57.21 \pm 5.39$ & $46.12-68.27$ & $11.01 \pm 0.66$ & $9.66-12.37$ & $7.19 \pm 0.45$ & $6.27-8.10$ \\
\hline (NL) & $79.5 \pm 2.82$ & $73.67-85.33$ & $17.57 \pm 3.53$ & $10.27-24.86$ & $64.26 \pm 4.68$ & $54.57-73.95$ & $10.08 \pm 0.51$ & $9.03-11.14$ & $7.05 \pm 0.68$ & $5.65-8.45$ \\
\hline$P$ value (ttest) & \multicolumn{2}{|l|}{0.5681} & \multicolumn{2}{|l|}{0.5506} & \multicolumn{2}{|l|}{0.3360} & \multicolumn{2}{|l|}{0.2817} & \multicolumn{2}{|l|}{0.8608} \\
\hline Parity $3(\mathrm{~L})$ & $92.47 \pm 5.02$ & $80.20-104.74$ & $7.41 \pm 3.49$ & $-1.13-15.96$ & $67.09 \pm 8.31$ & $46.74-87.43$ & $11.44 \pm 1.38$ & $8.06-14.82$ & $6.3 \pm 0.34$ & $5.47-7.13$ \\
\hline$(\mathrm{NL})$ & $76.08 \pm 4.37$ & $66.45-85.70$ & $25.17 \pm 8.45$ & $6.57-43.77$ & $45.74 \pm 8.49$ & $27.05-64.43$ & $10.37 \pm 1.02$ & $8.12-12.61$ & $5.99 \pm 0.58$ & $4.71-7.27$ \\
\hline$P$ value (ttest) & \multicolumn{2}{|l|}{0.0296} & \multicolumn{2}{|l|}{0.1410} & \multicolumn{2}{|l|}{0.1152} & \multicolumn{2}{|l|}{0.5357} & \multicolumn{2}{|l|}{0.7084} \\
\hline
\end{tabular}


Phosphorus level in lactating and non lactating cows were $6.52 \pm 0.308$ and $7.26 \pm 0.41 \mathrm{mg} / \mathrm{dl}$ respectively. According to Rowlands et al., (1974), phosphorus level was higher in dry cows than lactating. Peterson et al., (1981) also agreed the result of the present study where phosphorus low $(5.01 \pm 0.11 \mathrm{mg} / \mathrm{dl})$ in lactating than the dry period $(6.02 \pm 0.28 \mathrm{mg} / \mathrm{dl})$. Conversely Giuseppe et al., (2012) stated that, phosphorus level was higher in lactation than dry period. According to Patel et al., (1966) serum phosphorus level depends on climatic variation and the nature of the feed. Supplements of phosphorus in the diet have a very important role in blood phosphorus level of cow. The low level of dietary supplement of phosphorus is responsible for lower phosphorus level in serum (Kincaid et al., 2010). In a previous report serum phosphorus level was reported as $5.84 \pm 0.30 \mathrm{mg} / \mathrm{dl}$ in indigenous cow of Bangladesh (Mamun et al., 2013).

\section{Conclusions}

The result found that there is some biochemical difference between lactating and non lactating cow. Total protein and albumin is higher in non lactating cow than lactating cow, whereas glucose and calcium is higher in lactating cows. The phosphorus serum level is lower in lactating cow and higher in non- lactating cow. This may be due to seasonal, geographic, dietary, breed or other residual effect that needs further study. Subtropical conditions of the present study might have played a role in the differences with other studies. Finally biochemical values are an efficient tool for evaluation of physiological status, metabolic disorders, and management problems of the farm which have a great relation to health status of the animal and diagnosis of some pathos-physiological disorder in animals.

\section{Acknowledgements}

The authors are grateful to the respected farm members for their welcoming attitude during the study.

\section{Conflict of interest}

None to declare.

\section{References}

Aengwanich W, 2002. Effect of age on hematological values and blood profile of Holstein Friesian crossbred in Northeastern Thailand. Suranaree J. Sci. Technol., 9: 289-292.

Ahmed I, A Gohar, N Ahmed, M Ahmed, 2009. Haematological profile in cyclic and non- cyclic and Endometritic Cross breed Cattle. Int. J. Agr. Biol., 27: 83-91.

Al-Mujalli AAM, 2008. Studies on some serum constituents of dairy cows in saudi Arabia. Sci. J. King Faisal Univ. Basic Applied Sci., 9:105-113.

Al-Shami SA, 2007. Comparative study of haematological and blood biochemical components in milk-fed and conventionally-reared hassawi breed calves. Sci. J. King Faisal Univ. Basic Applied Sci., 8:99-106.

Cozzi G, L Ravarotto, F Gottardo, AL Stefani, B Contiero, L Moro, P Dalvit, 2011. Short communication: Reference values for blood parameters in Holstein dairy cows: effects of parity, stage of lactation, and season of production. J. Dairy Sci., 94: 3895-3901.

Daramola JO, AA Adeloye, TA Fatoba, AO Soladoye, 2005. Haematological and biochemical parameters of West African Dwarf goats.Livest. Res. Rural Dev., 17:3.

Etim NN, GU Enyenihi, U Akpabio, EE Offiong, 2014. Effects of nutrition on haematology of rabbits: a review. Eur. Sci. J., 10: 413-424.

Giuseppe P, M Vanessa, M Simona, C Stefania, G Claudia, F Francesco, 2012. Changes of some haematological parameters in dairy cows during late gestation, post partum, lactation and dry periods. Vet. Zootech. Lith. T., 58: 80.

Goff JP, TA Reinhardt, RL Horst, 1991. Enzymes and factors controlling vitamin D metabolism and action in normal and milk fever cows. J. Dairy Sci., 74: 4022-4032.

Hassan MM, MA Hoque, SKMA Islam, SA Khan, MB Hossain, Q Banu, 2012. Efficiency of anthelmintics against parasitic infections and their treatment effect on production and blood indices in Black Bengal goats in Bangladesh.Turk. J. Vet. Anim. Sci., 30: 400-408.

Horst RL, JP Goff, TA Reinhardt, 1990. Advancing age results in reduction of intestinal and bone 1, 25dihydroxyvitamin D receptor.Endocrinology,126:1053-1057.

Iriadam M, 2007. Variation in certain haematological and biochemical parameters during the peri-partum period in Kilis does. Small Ruminant Res., 73:54-57.

Kamiya Y, M Kamiya, M Tanaka,S Shioya, 2005. Effects of calcium intake and parity on plasma minerals and bone turnover around parturition. Anim. Sci. J., 76:325-330. 
Kaneko JJ, JW Harvey, ML Bruss, 1997. Clinical biochemistry of domestic animals (Academic Press 5th Ed. San Diego, London, Boston, New York, Sydney, Tokyo Toronto); 5:117-138.

Kincaid RL, JK Hillers, JD Cronrath, 2010. Calcium and Phosphorus Supplementation of Rations for Lactating Cows. J. Dairy Sci, 64:754-758.

Mamun MA, MM Hassan, AH Shaikat, SKMA Islam, MA Hoque, M Uddin, MB HossaiN, 2014.Biochemical analysis of blood of native cattle in the hilly area of Bangladesh.Bangladesh J. Vet. Med., 11:51-56.

Manzoor R, A Zahoor, SI Pampori, IA Javeed, MA Bhat, AK Manzoor, 2008. Hemato-Biochemical Indices of cross breed Cows during different stages of pregnancy. Indian J. Dairy Sci., 3: 154-159.

Matei ST, I Groza, S Andrei, L Bogdan, S Ciupe, APetrean, 2010. Serum metabolic parameters in healthy and subclinical mastitis cows. Bulletin UASVM Veterinary Medicine, 67:110-114.

Mohammed AK, G Mohammed, OO Akerejola, 2007. Haematological and serum biochemical changes in Bunaji work bulls after farmland ridging exercise in Kaduna State, Nigeria. J. Anim. Vet. Ad., 6: 576-579.

Ndlovu T, M Chimonyo, AI Okoh, V Muchenje, K Dzama, JG Raats, 2007. Assessing the nutritional status of beef cattle: current practices and future prospects. Afr. J. Biotechnol., $6: 2727-2734$.

Opara MN, KA Ike, IC Okoli, 2006.Haematology and Plasma Biochemistry of the Wild Adult African Grasscutter (Thryonomysswinderianus, Temminck). J. Am. Sci., 2: 17-22.

Patel BM, GN Menon, VV Mistry, 1996. Seasonal effect on the composition of blood in cattle.Indian Vet. J., 46:861-864.

Peterson RG, DE Waldern, 1981. Repeatabilities of serum constituents in Holstein Friesians affected by feeding, age, lactation and pregnancy. J. Dairy Sci., 64: 822-831.

Ramberg CF, GP Mayer, DS Kronfeld, JM Phang, M Berman, 1970. Calcium kinetics in cows during late pregnancy, parturition, and early lactation. Am. J. Physiol., 219:1166-1177.

Rowlands GJ, W Little, R Manston, SM Dew, 1974. The effects of season on the com- position of the blood of lactating and nonlactating cows as revealed from repeated metabolic profile tests on 24 dairy herds. J. Agri. Sci., 83:27.

Samardzjia M, T Dobranic, M Lipar, I Harapin, N Prvanovic, J Girzelji, G Gracner, V Dobranic, B Radisic, D Duricic, 2011. Comparison of blood serum macromineral concentrations in meat and dairy goats during puerperium. Vet. Arh.T., 81: 1-11.

Tambuwal FM, BM Agaie, B Bangana, 2002. Haematological and serum biochemical values of apparently healthy red Sokoto goats. Proceedings of the 27th Annual Conference ofthe Nigerian Society for Animal Production; pp. 50-53.

Tanritanir P, S Dede, E Ceylan E, 2009. Changes in some macro minerals and biochemical parameters in female healthy siirt hair goats before and after parturition. J. Anim. Vet. Adv., 8: 530-533.

Van Saun RJ, M Wustenberg, 1997. Metabolic profiling to evaluate nutritional and disease status. Bovine Pract., $1: 37-42$. 